\title{
DIFFERENT WAYS OF IMPROVING BIOMASS EFFICIENCY OF POULTRY EXCRETA FOR BIOGAS PRODUCTION
}

\author{
Odinaka Christian, IWUOZO \\ Department of Animal Science, \\ Faculty of Agriculture, \\ University of Benin, \\ Benin City, Nigeria
}

\author{
Festus Ufochukwu, EZUE \\ Department of Animal Science, \\ Faculty of Agriculture, \\ University of Benin, \\ Benin City, Nigeria
}

\author{
Julius Mark, OLOMU \\ Department of Animal Science, \\ Faculty of Agriculture, \\ University of Benin, \\ Benin City, Nigeria
}

\begin{abstract}
With the increasing production of poultry excreta globally, there is vast need to harness the excreta output for better welfare of mankind through sustainable energy generation and biogas production. To improve the excreta output for adequate biogas production, twenty broiler chickens were fed diet containing Siam leaf meal (SLM), while the other twenty were not. Also, the poultry excreta (both with or without SLM diet) was mixed with wheat bran (WB) at ratio of $3: 1$, crushed and analyzed for the various parameters. For nutrient composition, crude fibre content and nitrogen free extract, fat content was better in SLM diet and with addition of WB, compared when no SLM diet plus WB was involved, while the crude protein and dry matter content are appropriate in all the groups. The carbohydrate, protein and lipid compositions in the biomass were optimum for bacteria activities during biogas production. The carbon to nitrogen ratio (C: $N$ ) obtained in this study, is consistent with the $\mathrm{C}$ : $\mathrm{N}$ ratio optimum for methanogenic activities of between 20: to 30:1 with better C: $N$ ratio recorded in SLM diet and SLM diet plus WB. The total solids in all the groups had similar values, which indicates the easy for microbial mobility and biogas yield, while volatile solid content of the biomass is ideal for bacteria degradation. And the increased values of total solid- volatile solid ratio recorded could support huge methane generation. Gross energy in SLM diet and SLM diet plus WB showed high capabilities to convert the biomass to methane. It is obvious that the improved poultry excreta have great potential for enormous biogas yield. Therefore, it is advised that use of SLM and WB be adopted by poultry researchers and biogas producers.
\end{abstract}

Keywords: Biogas, biomass, methane, poultry excreta, Siam leaf meal, wheat bran

\section{INTRODUCTION}

The effective e disposal and management of poultry excreta have become a major concern globally with the rapid increase in the population and poultry production [1]. Large production of this organic waste poses offensive and environmental challenges [2], therefore, well managed disposal of this waste is very necessary in the maintenance of healthy environmental status [3]. To harmonize the interest of poultry industry with current and future environmental concerns, environmental stewardship in animal agriculture is aimed at mitigation of contamination of the environment by excreta.

The recent development in sustainable management of poultry excreta by improving the biomass and harnessing its enormous potentials as an alternative source of biogas production is gaining prominence [ 1 , 4]. Chromolaena odorata (Siam weed) is widely utilized in animal feed for poultry and other livestock especially in the tropics [5]. The leaves are easily dried, blended and utilized as supplement in the animal as leaf meal. The nutritional values of the Siam leaf meal (SLM) makes it an excellent potential for livestock feeding in the tropics due its high crude protein and crude fibre contents [6] thereby should yielding better excreta output. As result, it has increased the need for SLM to be used in supplementing livestock feed and for efficient livestock production. Furthermore, the potentials of the Siam leaf meal as an effective biomass for biogas generation when mixed with cow waste in appropriate proportion is known to favour methanogenic activities $[7,8,9]$. Also, use of improvers like wheat bran, brewery dry grain, maize straw among others have contributed to the better generation of biogas unlike when only poultry waste is utilized for such purpose [10]. Wheat bran had been explored for its enormous potential in biogas production as biomass [11], 


\section{International Journal of Engineering Applied Sciences and Technology, 2020 \\ Vol. 4, Issue 9, ISSN No. 2455-2143, Pages 84-90 \\ Published Online January 2020 in IJEAST (http://www.ijeast.com)}

ranking it as one of the foremost biomass for biogas generation globally $[12,13]$.

For effective digestion of the biomass, nutrients such as carbohydrates, proteins and lipids, are usually broken down by several activities in the biogas production phase to enrich the bacteria [14], these nutrients integration is dependent on the ability of these bacteria to exploit carbon related compounds [15] of the substrate which they decomposed readily to yield biogas with sufficient nitrogen $(\mathrm{N})$ contents in the biomass [16]. However, excellent carbon to nitrogen ratio $(\mathrm{C}: \mathrm{N})$ are required for the growth and maintenance of the methanogens [17], but very high level of $\mathrm{C}$ : $\mathrm{N}$ ratio will limit the microbial activities [18]. Methane generation from the poultry excreta is a result of biodegradation of its total solids (TS), defined as the mass remained when moisture content is removed [19]. The higher the TS, the more organic matter is digested by the methanogens [20]. The biodegradable component or organic matter is the mass which is removed when dry matter is heated (from $105^{\circ} \mathrm{C}$ to $550^{\circ} \mathrm{C}$ ) known as the volatile solid (VS), this varies depending on the biomasses [19]. Gross energy as the net energy yield, defines the convertibility of biomass to methane [21], as this parameter is very important indicator of the biomass to yield enormous biogas. The aim of this study was to investigate different ways biomass (poultry excreta) can be improved efficiently for biogas production by feeding the birds with Siam leaf meal and using plant materials like wheat bran.

\section{MATERIALS AND METHODS}

\section{A. Materials}

The experiment and chemical laboratory analyses were conducted in the University farm project and main laboratory of the Faculty of Agriculture, University of Benin, Benin City Nigeria. A total of forty (40), five (5) weeks broiler chickens were used in the experiment. The broilers were kept in deep litter system and prior to the arrival of the birds, wood shavings (litters) was spread on the floor, where the poultry droppings were obtained. Twenty birds were fed diet from the commercially available broiler ration, while the other twenty were fed compounded diet containing Siam leaf meal (SLM), Chromolena odorata to replace both maize and soya bean meal. The diets were provided ad libitum for two weeks, and thereafter the poultry excreta were collected. The samples (poultry excreta) from broilers with or without Siam leaf meal diets were crushed and mixed with wheat bran at a proportion of 3:1 (poultry excreta: wheat bran).

\section{B. Methods}

The samples were assayed for proximate composition which involved the determination of dry matter, crude fibre, crude protein, ether extract, ash content and nitrogen free extract. Dry matter was determined by drying samples in vacuum oven at $105^{\circ} \mathrm{C}$ for 24 hours. Total nitrogen $(\mathrm{N})$ was determined by Kjeldahl method [22] and crude protein (CP) was calculated as $\mathrm{N} x$ 6.25. Ether extract was determined by extracting the samples with petroleum ether using the Soxhlet method [22]. Crude fibre content was determined by gravimetric method that measured the organic residue remaining after sequential digestion with $0.255 \mathrm{~N}$ sulphuric acid and $0.313 \mathrm{~N}$ sodium hydroxide solutions, followed by oven- drying at $105^{\circ} \mathrm{C}$ overnight and incinerate in muffle furnace at $550^{\circ} \mathrm{C}$ for 3 hours and ash content was determined by combusting $2 \mathrm{~g}$ of the samples at $550^{\circ} \mathrm{C}$ to $850^{\circ} \mathrm{C}$, while nitrogen free extract (NFE) was calculated thus: (100$\mathrm{CP}+\mathrm{EE}+\mathrm{MC}+\mathrm{Ash}+\mathrm{CF})[22]$.

The organic carbon content of the samples was determined using Walkley and Black [23] method. The reagent was prepared by weighing $49 \mathrm{~g}$ of potassium dichromate and diluted to 1 litre with distill water. Ferrous sulphate was prepared by dissolving $140 \mathrm{~g}$ in distilled water and the solution was acidified by the addition of $15 \mathrm{ml}$ concentrated sulphuric acid. A blank (containing potassium dichromate solution, concentrated sulphuric acid and distill water) was made and titrated to standardize the potassium dichromate. A representative sample $1 \mathrm{~g}$ was weighed into $250 \mathrm{ml}$ conical flasks. $10 \mathrm{ml}$ of potassium dichromate solution was pipetted into the flask. A $20 \mathrm{ml}$ concentrated sulphuric acid was added rapidly using measuring cylinder, the flask was made to stand for 30 minutes to cool. Using a measuring cylinder, $100 \mathrm{ml}$ of distilled water was added to increase the volume of the mix in the beaker. Then, 10 drops of ferroin indicator was also added to the mixture. Titration with $0.5 \mathrm{~N}$ ferrous sulphate solution until endpoint was reached, where the solution changed from greenish cast to maroon colour. However, the \% Carbon was determined as follows;

$\%$ Carbon $=\frac{(\mathrm{B}-\mathrm{t}) \times \mathrm{n} \times 0.003 \mathrm{~F}}{\text { Weight of sample }} \times \frac{100}{1}$

Where, $\mathrm{n}=0.5, \mathrm{~F}=1.33, \mathrm{~B}=$ Blank value and $\mathrm{t}=$ titre value

The carbon to nitrogen ratio $(\mathrm{C}: \mathrm{N})$ was obtained by dividing carbon content by nitrogen content. 


\section{International Journal of Engineering Applied Sciences and Technology, 2020 \\ Vol. 4, Issue 9, ISSN No. 2455-2143, Pages 84-90 \\ Published Online January 2020 in IJEAST (http://www.ijeast.com)}

Total solid (TS) content was determined by weighing $2 \mathrm{~g}$ of the substrate and dried in an oven at $105^{\circ} \mathrm{C}$ at 3 hours to obtain the dry matter mass. The dry matter sample was then weighed and put in muffle furnace at $550^{\circ} \mathrm{C}$ for 2 hours, and then removed and placed in desiccator for cooling. After cooling, the sample was weighed to obtain the volatile component of the sample (organic matter). According to method of [19] and [24], total solid and volatile solid were calculated as follows;

$\%$ Total solid $(\mathrm{TS})=\frac{\text { Mass of dry matter }}{\text { Mass of substrate }} \times \frac{100}{1}$

$\%$ Volatile solid $(\mathrm{VS})=\frac{\text { Mass of organic matter }}{\text { Mass of dry matter }} \times \frac{100}{1}$

The total solid to volatile solid ratio was obtained by dividing the total solid by the volatile solid

Gross energy level was calculated by the method of [25] using;

Gross energy $(\mathrm{MJ} / \mathrm{Kg})=(2.62 \mathrm{x} \%$ Protein $)+(8.37 \mathrm{x}$ $\%$ Fat $)+(4.2 \times \%$ Carbohydrates $)$.

The data obtained were subjected to analysis of variance (ANOVA) in a randomized complete block design as described by [26], and F- test to compare the means. Least significant difference (LSD) test was used to determine the significant differences among the means.

\section{RESULTS}

The proximate composition of broiler excreta with and without Siam leaf meal; and the broiler excreta with wheat bran at 3:1 ratio respectively is shown in Table 1. The treatment without Siam leaf meal (SLM) fed diet plus wheat bran had lower $(\mathrm{p}<0.05)$ dry matter (DM) content from other treatments which were not significantly $(\mathrm{p}>0.05)$ different from each other but higher than previous. Group fed SLM recorded least $(\mathrm{p}<0.05)$ values for crude protein $(6.69 \pm 0.82 \%)$ compared to other treatment groups $(6.81 \pm 0.82$ vs $7.13 \pm 0.82$ vs $6.81 \pm 0.82 \%$ ) which indicates that other groups are better in CP than group with SLM diet only. The ash content of the groups without SLM and with SLM plus wheat bran had higher $(\mathrm{p}<0.05)$ values compared to groups with SLM and without SLM plus wheat bran $(6.25 \pm 1.02$ vs $4.13 \pm 1.02$ and $3.86 \pm 1.02$ vs $2.12 \pm 1.02$ respectively). Highest $(\mathrm{p}<0.05)$ crude fibre content was recorded in the group with SLM plus wheat bran showing the availability of digestible carbon material for enormous biogas generation and least values recorded in group without SLM plus wheat bran, while intermediate values obtained in groups without improver with or without SLM diet. A higher ether extract was obtained in groups without SLM diet (with or without wheat bran) while lower values obtained in groups with SLM diets which suggest that the SLM could have suppressed the lipids content of the poultry biomass. For nitrogen free extract $(\mathrm{NFE})$, higher $(\mathrm{p}<0.05)$ values were recorded in groups with SLM diet (with or without wheat bran) compared to groups without SLM diet (with or without wheat bran) which implies that the diet and the wheat bran raised the carbohydrate level of the biomass for effective methanogenic activities and biogas generation.

Table 1: Proximate composition of broiler excreta with and without Siam leaf meal; and the broiler excreta with wheat bran at 3:1 ratio respectively (DM basis)

\begin{tabular}{|c|c|c|c|c|c|c|}
\hline \multirow[t]{2}{*}{ Treatments } & \multicolumn{5}{|c|}{ Parameters } & \multirow[b]{2}{*}{ NFE (\%) } \\
\hline & $\mathrm{DM}(\%)$ & $\mathrm{CP}(\%)$ & Ash (\%) & $\mathrm{CF}(\%)$ & $\mathrm{EE}(\%)$ & \\
\hline B1-SLM & $87.39 \pm 1.08^{a}$ & $6.81 \pm 0.82^{\mathrm{a}}$ & $6.25 \pm 1.02 \mathrm{a}$ & $22.75 \pm 2.95 b$ & $6.80 \pm 1.12 \mathrm{a}$ & $50.00 \pm 3.77^{b}$ \\
\hline B2+SLM & $87.15 \pm 1.08^{a}$ & $6.69 \pm 0.82^{b}$ & $3.86 \pm 1.02^{\mathrm{b}}$ & $23.25 \pm 2.95^{\mathrm{b}}$ & $3.50 \pm 1.12^{\mathrm{b}}$ & $52.92 \pm 3.77^{\mathrm{a}}$ \\
\hline$(\mathrm{B} 2+\mathrm{SLM})+\mathrm{WB}$ & $88.54 \pm 1.08^{a}$ & $6.81 \pm 0.82^{\mathrm{a}}$ & $4.13 \pm 1.02^{\mathrm{a}}$ & $26.25 \pm 2.95^{\mathrm{a}}$ & $3.30 \pm 1.12^{\mathrm{b}}$ & $55.62 \pm 3.77^{\mathrm{a}}$ \\
\hline
\end{tabular}

a, b, c, implies that means within columns with different superscripts are significantly different $(\mathrm{p}<0.05)$

As shown in Table 2, carbon to nitrogen ratio of broiler excreta with and without Siam leaf meal; and the broiler excreta with wheat bran at 3:1 ratio respectively are obtained. The carbon content of group fed SLM diet plus wheat bran had highest $(\mathrm{p}<0.05)$ values, intermediate $(\mathrm{p}<0.05)$ values recorded in group without SLM diet plus wheat bran, and least $(\mathrm{p}>0.05)$ values recorded in groups with or without SLM diet. A higher $(p<0.05)$ nitrogen content was obtained in group without SLM diet plus wheat bran compared to other groups. The carbon to nitrogen ratio $(\mathrm{C}: \mathrm{N})$ of groups fed SLM diet (with or without wheat bran) had higher $(\mathrm{p}<0.05)$ values compared to the groups not fed SLM diet (with or without wheat bran). 


\section{International Journal of Engineering Applied Sciences and Technology, 2020 \\ Vol. 4, Issue 9, ISSN No. 2455-2143, Pages 84-90 \\ Published Online January 2020 in IJEAST (http://www.ijeast.com)}

Table 2: Carbon to nitrogen ratio of broiler excreta with and without Siam leaf meal; and the broiler excreta with wheat bran at 3:1 ratio respectively (DM basis)

\begin{tabular}{llll}
\hline Treatments & \multicolumn{3}{c}{ Parameters } \\
\cline { 2 - 4 } & Carbon $(\%)$ & Nitrogen $(\%)$ & Carbon: Nitrogen \\
\hline B1-SLM & $22.16 \pm 0.53^{\mathrm{c}}$ & $1.09 \pm 0.09^{\mathrm{b}}$ & $20.33 \pm 1.41^{\mathrm{b}}$ \\
B2+SLM & $22.65 \pm 0.53^{\mathrm{c}}$ & $1.07 \pm 0.09^{\mathrm{b}}$ & $21.17 \pm 1.41^{\mathrm{a}}$ \\
& & & \\
$(\mathrm{B} 1-\mathrm{SLM})+\mathrm{WB}$ & $23.56 \pm 0.53^{\mathrm{b}}$ & $1.14 \pm 0.09^{\mathrm{a}}$ & $20.67 \pm 1.41^{\mathrm{b}}$ \\
& & & $22.14 \pm 1.41^{\mathrm{a}}$ \\
(B2+SLM) +WB & $24.13 \pm 0.53^{\mathrm{a}}$ & $1.09 \pm 0.09^{\mathrm{b}}$ & $2.05)$
\end{tabular}

$\mathrm{a}, \mathrm{b}, \mathrm{c}$ implies that means within columns with different superscripts are significantly different $(\mathrm{p}<0.05)$

In Table 3, the total and volatile solids of broiler excreta with and without Siam leaf meal; and the broiler excreta with wheat bran at $3: 1$ ratio respectively is shown. The treatment without SLM fed diet plus wheat bran had lower $(\mathrm{p}<0.05)$ values for total solids compared to the other groups, which were not different $(p>0.05)$ from each other. For volatile solids (VS), the group without SLM diet had higher $(p<0.05)$ values for VS than group with SLM diet, while group without SLM diet plus wheat bran recorded lower $(\mathrm{p}<0.05)$ VS compared to group with SLM diet plus wheat bran. The total solid to volatile solid ratio (TS: VS) of group without SLM diet plus wheat bran recorded highest $(\mathrm{p}<0.05)$ values, while the least $(p<0.05)$ values recorded in group without SLM diet, and intermediate $(\mathrm{p}>0.05)$ values recorded in groups with SLM diet (with or without wheat bran).

Table 3: Total solids and volatile solids of broiler excreta with and without Siam leaf meal; and the broiler excreta with wheat bran at 3:1 ratio respectively (DM basis)

\begin{tabular}{llll}
\hline Treatments & \multicolumn{3}{c}{ Parameters } \\
\cline { 2 - 4 } & TS $(\%)$ & VS $(\%)$ & TS: VS \\
\hline B1-SLM & $87.39 \pm 1.08^{\mathrm{a}}$ & $7.13 \pm 1.04^{\mathrm{a}}$ & $12.26 \pm 0.82^{\mathrm{c}}$ \\
B2+SLM & $87.15 \pm 1.08^{\mathrm{a}}$ & $4.41 \pm 1.04^{\mathrm{b}}$ & $19.76 \pm 0.82^{\mathrm{b}}$ \\
(B1-SLM) +WB & $86.36 \pm 1.08^{\mathrm{b}}$ & $2.45 \pm 1.04^{\mathrm{b}}$ & $35.25 \pm 0.82^{\mathrm{a}}$ \\
(B2+SLM) +WB & $88.54 \pm 1.08^{\mathrm{a}}$ & $4.66 \pm 1.04^{\mathrm{a}}$ & $19.00 \pm 0.82^{\mathrm{b}}$ \\
\hline
\end{tabular}

$\mathrm{a}, \mathrm{b}, \mathrm{c}$ implies that means within columns with different superscripts are significantly different $(\mathrm{p}<0.05)$

B1-SLM: $\quad$ Broiler litter without Siam leaf meal diet

B2+SLM: $\quad$ Broiler litter with Siam leaf meal diet

(B1-SLM) + WB: Broiler litter without Siam leaf meal diet + Wheat Bran

$($ B2+SLM $)+$ WB: Broiler litter with Siam leaf meal diet + Wheat Bran

Figure 1, shows the gross energy level of broiler excreta with and without Siam leaf meal; and the broiler excreta with wheat bran at 3:1 ratio respectively. The highest gross energy was obtained in group fed SLM diet, followed by groups fed SLM diet plus wheat bran, and group (without SLM diet plus wheat bran) while least gross energy level obtained in group without SLM diet. 


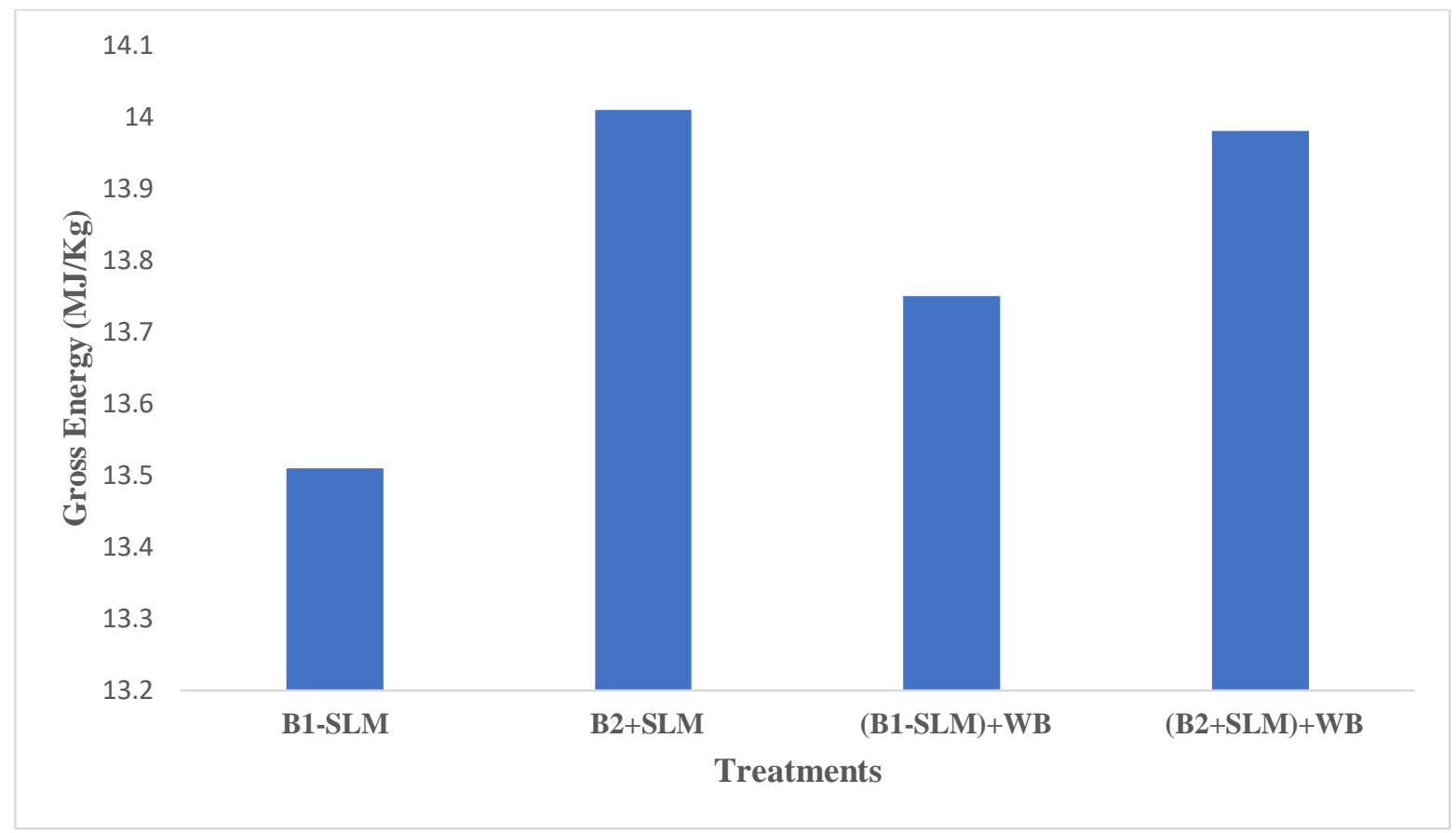

Figure 1: Gross energy level of broiler excreta with and without Siam leaf meal; and the broiler excreta with wheat bran at 3:1 ratio respectively (DM basis)

\section{DISCUSSION}

As the need for improving biomass efficiency of poultry excreta for biogas production in sustainable energy generation is expedient, the gross nutrient composition of samples must be totally examined. The dry matter content of the biomass in all the groups is a good indication of the suitable environmental conditions for microbial activities and biogas production. The least dry matter content of biomass is close to that obtained by [1] of $86.5 \%$ dry matter content (that is, $13.5 \%$ moisture content). Carbohydrate (in form of crude fibre and nitrogen free extract), proteins and lipids are very essential for nutrient availability to the bacteria during digestion phase in biogas production [14]. Also, the utilization of the substrates (nutrients) is dependent on the capability of the anaerobic bacteria to assimilate the carbon compounds maximally [15]. The methane generation is dependent on the biodegradable component such as ash content (mineral elements) necessary for activation of co-enzymes of the methanogens [16]. But, very high fat content in the biomass could limit the microbes' ability to degrade organic matter, and excessive crude fibre fraction of the biomass could pose challenge to the microbes to break down and make the nutrients available, due to presence of insoluble lignin [27].
One of the major factors for biogas production is the carbon to nitrogen ratio. Microorganisms need both carbon and nitrogen for its cell growth and development $[17,19]$. The good anaerobic digestion of organic nutrients requires $\mathrm{C}: \mathrm{N}$ ratio of between 20:1 and 30:1 for optimum biogas yield $[16,28]$. This implies that the $\mathrm{C}: \mathrm{N}$ ratio obtained from this study is appropriate for biogas production especially with the improvement of the poultry excreta.

The total solids of the biomass are useful as marker to loading rate of the digester in the anaerobic condition and are crucial in the effective agility of methaneforming bacteria during digestion [29]. The TS of biomass in this study are within the range for biogas production, when compared with $[1,30,20]$. The volume of methane generated is dependent on the available volatile solid, that is amounts of solids present in the biomass that can be degradable to methane [31]. The VS for biogas production in this study are lower and not within the range of $[1,30,20]$. The total solid- volatile solid ratio attributes to the efficiency of biogas production, as low or high TS/VS ratio have either negative or positive influence on the methane production. The high TS/VS ratio obtained in this study is supported by of [32], which reported that increased TS/VS ratio also increases the production of methane. 


\section{International Journal of Engineering Applied Sciences and Technology, 2020 \\ Vol. 4, Issue 9, ISSN No. 2455-2143, Pages 84-90 \\ Published Online January 2020 in IJEAST (http://www.ijeast.com)}

Gross energy is very important to ascertain the potentiality of biomass for biogas production, which defines the convertibility of biomass to methane [21]. The gross energy of biomass in this study is close that reported by [33] of $14.79 \mathrm{MJ} / \mathrm{kg}$ and far better than that reported by [34] of $6.11 \mathrm{MJ} / \mathrm{Kg}$. The best gross energy of biomass could be attributed to the SLM diet and addition of wheat bran.

\section{CONCLUSION}

Since poultry excreta are known to constitute a public nuisance and to manage its outputs sustainably have been an issue to many researchers and environmentalists, it could be best to utilize the excreta for well-being of mankind by generation of biogas from the poultry waste. In this study, it could be concluded that the nutrient composition of the biomass is suitable for the bacteria activities in the biogas production. Carbon to nitrogen ratio of the improved biomass are within the optimum range for methanogenic activities, therefore it is an excellent substrate for biogas production. The TS of the improved biomass is sufficient for mobility of methanogens while VS is conducive for biodegradation of the biomass by the microorganisms for good methane generation. The improved broiler excreta have great potential for biogas production since the gross energy values are very high. It can therefore be recommended that efficient use of Siam leaf meal diet and wheat bran be adopted by many poultry nutrition researchers and biogas producers.

\section{ACKNOWLEDGEMENT}

The authors are pleased to appreciate the efforts and contributions of the members of staffs of Animal Science department, University of Benin City and the laboratory team for the conducive environment of this research.

\section{REFERENCES}

[1] Oyewole, O.A. 2010. Biogas production from chicken droppings. Science World Journal, 5(4):1114.

[2] Edwards, C.A. and Bater, J.E. 1992. The use of earthworms in environmental management. Soil Biology and Biochemistry 24: 1683-1689.

[3] Senapati, B.K. and Julka, J.M. 1993. Selection of suitable vermicomposting species under Indian conditions. Earthworm resources and vermiculture, p. 113.
[4] Neupane, S.K. 2018. Biogas production from poultry faeces. Innovative Energy and Research, 7(4):220.

[5] Imasuen, J.A. Osa, U.G.S. and Nwokoro, S.O. 2017. The Effect of Chromolaena Odorata (Siam Weed) on the Haematological Profile and Growth Performance of Rabbits. IOSR Journal of Agriculture and Veterinary Science, 10(9): 01-04.

[6] Apori. S.O., Long, R.J., Castro, F.B. and trskov, E.R. 2000. Chemical composition and nutritive value of leaves and stems of tropical weed Chromolaena odorata. Grass and Forage Science, 55: 77-81.

[7] Jagadeesh, K. S., Geeta, G. S. and Suvarna, C. V. 1993. Biogas from Eupatorium odoratumL. Current Research - University of Agricultural Sciences (Bangalore) 22(1): 9-11.

[8] Sapkota, T., Aryal, J., Thapa, S. and Karki, A.B. 2012. Biogas Production from Anaerobic Digestion of Different Biodegradable Materials. Nepal Journal of Science and Technology, 13 (2): 123-128.

[9] Sudhakar, K., Ananthakrishnan, R. and Goyal, A. 2013. Biogas production from a mixture of Water Hyacinthm, Water Chestnut and Cow Dung. International Journal of Sciences, Engineering and Technology, 2 (1): 35-37.

[10] Keller, B.P. 2002. Advances in poultry litter disposal technology- A review. Bioresource Technology, 83:27-36.

[11] Tsavkelova, E.A. and Netrusov, A.I. 2012. Biogas production from cellulose containing biomass: a review. Applied Biochemistry and Microbiology, 48:421-433.

[12] Wang, G., Gavala, H.N., Skiadas, I.V. and Ahring, B.K. (2009). Wet explosion of wheat straw and co-digestion with swine manure: effect on the methane productivity. Waste Management 29:28302835.

[13] Ewa, K., Tomasz, P., Wojciech, B. and Bogdan, D. 2010. Theoretical and observed biogas production from plant biomass of different fibre contents. Bioresource Technology, 101:9527-9535. [14] Uzodinma, E.O. and Ofoefule, A.U. 2009. Biogas production from blends of grass, with some animal wastes. International Journal of Physical Sciences, 4 (2): 91-93.

[15] Cantrell, K.B., Ducey, S.R., Kyoung, M.E. and Hunt, P.G. 2008. Livestock waste-to-bioenergy 


\section{International Journal of Engineering Applied Sciences and Technology, 2020 \\ Vol. 4, Issue 9, ISSN No. 2455-2143, Pages 84-90 \\ Published Online January 2020 in IJEAST (http://www.ijeast.com)}

generation opportunities. Bioresource Technology, 99(17) :7941-7953.

[16] Mshandete, A.M and Parawira, W. 2009. Biogas technology research in selected subSaharan African countries - A review. African Journal of Biotechnology 8(2): 116-125.

[17] Weiland P. 2010. Biogas production: current state and perspectives. Applied Microbiology and Biotechnology, 85(4): 849-860.

[18] Sun, L., Muller, B. and Schnurer, A. 2013. Biogas production from wheat straw: community structure of cellulose-degrading bacteria. Energy, sustainability and society, 3:15.

[19] Oyeleke, S.B., Onigbajo, H.O. and Ibrahim, K. 2003. Degradation of animal wastes (cattle dung) to produce methane (cooking gas). Proceedings of the Eighth Annual Conference of Animal Science Association of Nigeria (ASAN). Pp. 168-169.

[20] Nnabuchi, M. N., Akubuko, F. O., Augustine, C. and Ugwu, G. Z. 2012. Assessment of the effect of codigestion of chicken dropping and cow dung on biogas generation. International Research Journal of Engineering Science, Technology and Innovation (IRJESTI). 1 (9): 238-243.

[21] Lehtonmaki, A. 2006. Biogas production from energy crops and crop residues. Jyvaskyla Studies in Biological and Environmental Science 163:1-94.

[22] AOAC (2000) Official Methods of Analysis. 17th Edition, The Association of Official Analytical Chemists, Gaithersburg, MD, USA. Methods 925.10, 65.17, 974.24, 992.16.

[23] Walkley, A. and Black, I.A. 2006. An examination of the Degtjareff method for degerming soil organic matter and a proposed modification of the chromic acid titration method. Soil Science, 37:29-38.

[24] Thy, S., Preston, T.R., Ly, J. 2003. Effect of retention time on gas production and fertilizer value of bio-digester effluent. Livestock Research for Rural Development. 15(7), article \#53. Retrieved October 5, 2019.

[25] Crisan, E.V. and Sands, A. 1978. The Biology and Cultivation of Edible Mushrooms," Nutritional Value, Academic Press, New York, pp. 137-168.

[26] Statistical Analysis System (2001) User's Guide: Statistics, Version 8.2. SAS Institute, NC, USA.
[27] Singh, R., Behera, S., Yadav, Y.K. and Kumar, S. 2014. Potentials of wheat straw for biogas production using thermophiles. Recent Advances in Bioenergy Research, 3:242-249.

[28] Dioha, I.J., Ikeme, C.H., Nafi'u, T., Soba, N.I. and Yusuf, M.B.S. 2013. Effect of carbon to nitrogen ratio on biogas production. International Research Journal of Natural Sciences. 1(3): 1-10.

[29] El-Mashad, H.M., Zeeman, G., van Loon, W.K.P., Bot, G.P.A., and Lettinga, G. 2004. Effect of Temperature and Temperature Fluctuation on Thermophilic Anaerobic Digestion of Cattle Manure. Bioresource Technology, 95(2): 191-201.

[30] Ofoefule, A.U., Uzodinma, E.O., Anyanwu, C.N. 2010. Studies on the effect of anaerobic digestion on the microbial flora of Animal Wastes: Digestion and Modelling of Process Parameters. Trends in Applied Sciences Research. 5 (1): 39-47.

[31] Wilkie, A.C. (2003). Anaerobic Digestion of Flushed Dairy Manure. Proceedings - Anaerobic Digester Technology Applications in Animal Agriculture - A National Summit, from the Water Environment Federation.

[32] Karim, K., Klasson, K. T., Hoffmann, R., Drescher, S.R., DePaoli, D.W., and Al-Dahhan, M.H. 2005. Anaerobic Digestion of Animal Waste: Effect of Mixing. Bioresource Technology, 96(14): 1607-1612.

[33] Polin, C.B., Varghese, M., Neff, M., Zindel, H. and Gomez, C.J. 1971. The metabolizable energy value of dried poultry waste. Resource Report No. 152 Michigan Agricultural experimental station pp 32.

[34] Ilaboya, I.R., Askhame, F.F., Ezugwu, M.O., Erameh, A.A. and Omofuma, F.E. 2010. Biogas generation from agricultural waste, analysis of the effect of alkaline on gas creation. World Applied Science. 9 (5): 537-545. 